\title{
Stage IV Gastric Cancer AJCC v7
}

National Cancer Institute

\section{Source}

National Cancer Institute. Stage IV Gastric Cancer A/CC v7. NCI Thesaurus. Code C89861.

Stage IV includes: (Any T, Any N, M1). M1: Distant metastasis. (AJCC 7th ed.) 